UDC 577.29::575.24:616-006.487/-092.6

\title{
EXPRESSION OF MIR-34 FAMILY OF microRNA AND CLINICAL OUTCOME OF NEUROBLASTOMA
}

\author{
M. Inomistova ${ }^{1,2}$, N. Khranovska ${ }^{1}$, O. Skachkova ${ }^{1}$, E. Shaida ${ }^{1}$, S. Demydov ${ }^{2}$ \\ ${ }^{1}$ National Cancer Institute, Lomonosov St., 33/43, Kyiv 03022, Ukraine \\ e-mail:m.inomistova@gmail.com \\ 2 Taras Shevchenko National University of Kyiv \\ 64, Volodymyrska St., Kyiv 01601, Ukraine
}

Neuroblastoma is one of the most common cancers in children that arises from sympathetic nervous system tissue with a high rate of incidence in Ukraine. Genetic abnormalities containing loss of chromosome 1p36 and 11q, MYCN amplification are strongly associated with poor prognosis of this disease.

Despite rare TP53 mutations, p53 pathway is often inactivated in neuroblastoma, mostly by MDM2 overexpression. Members of miR-34 microRNA family are the most prevalent p53-induced miRNAs and important mediators of tumor suppression. MiR-34 microRNA family consists of three members: miR-34a is encoded by its own transcript from $1 \mathrm{p} 36$, whereas miR-34b and miR-34c share a common primary transcript in 11q. It is suggested that miR-34a is a suppressor of neuroblastoma tumor genesis, as it targets many oncogenes such as E2F3, BCL-2 and MYCN.

In this study, we present evidence of miR-34 deregulation in neuroblastoma. A decrease of miR-34 expression was associated with unfavorable clinical and biological features of the disease. Low miR-34a expression was associated with a decrease of survival rates in groups of patients with MDM2 overexpression and MYCN not-amplified low expressed MDM2 neuroblastoma. Taking this into account, analysis of mir-34a expression can help to improve personalized therapy strategy and serve as additional marker for the stratification optimization in patients with neuroblastoma.

Keywords: neuroblastoma, miR-34 microRNA family, expression, clinical outcome.

\section{INTRODUCTION}

Neuroblastoma (NB) is the most common extracranial solid childhood tumor. It is responsible for $\sim 15 \%$ of all childhood cancer mortality with a high rate of incidence in Ukraine and worldwide. NB originates from immature sympathetic nervous system cells, and almost all NBs (90 \%) are diagnosed in patients younger than 5 years, with the median age of occurrence being around 22 months [10]. The most of tumors are found in the abdomen ( $65 \%)$, often in the adrenal medulla, or elsewhere in the body where sympathetic nervous system components are present [3]. This disease displays remarkable 
heterogeneity in clinical behavior, ranging from spontaneous regression to rapid progression, metastasizing and resistance to the therapy. The clinically heterogeneous nature of NB partly arises from its biological and genetic heterogeneity. Moreover, genetic and molecular findings are now routinely considered in therapeutic decision making. Amplification of the MYCN gene and a complex set of chromosomal aberrations are characte ristic of poor NB prognosis, including 1p36 deletion, 11q deletion, and 17q gain $[1,2,8]$.

MiRNAs are non-coding, single-stranded RNAs consisting of approximately 2225 nucleotides, and they constitute a novel class of gene regulators. They negatively regulate their targets in one of two ways, depending on the degree of complementarity between the miRNA and the target. MiRNAs exert their regulatory effects through binding with canonical 7-8 nucleotide complementary sites, called "seeds," within the $3^{\prime}$ untranslated regions (UTRs) of their mRNA targets. The other post-transcriptional repression mechanisms in which miRNAs use their central region to pair to their targets or in which miRNAs can simultaneously bind 5'-UTR and $3^{\prime}-$ UTR motifs through their $3^{\prime}$ - and 5'-end sequences, respectively, to drive mRNA cleavage [2]. In general, the translational control mechanism used by miRNAs to reduce the protein levels of their target genes implies that the mRNA levels of these genes might be affected.

MiR-34 microRNA family consists of three members: miR-34a, b, and c. In mammalians, the miR-34 microRNA family comprises three processed miRNAs that are encoded by two different genes: miR-34a is encoded by its own transcript from 1p36.22 chromosome, whereas miR-34b and miR-34c share a common primary transcript in 11q23.1 chromosome. These chromosomal regions are often deleted in the NB (Fig. 1) and are associated with unfavorable NB outcome. In mice, miR-34a is ubiquitously expressed with the highest expression in brain, whereas miR-34b/c is mainly expressed in lung tissues. MiR-34a is expressed at higher levels than miR-34b/c, with the exception of the lung, in which miR-34b/c is dominantly expressed. Therefore, the two miR-34 genes presumably have tissue-specific functions [4].

Despite rare TP53 mutations, p53 pathway is often inactivated in the NB. Deletion of TP53 occurs mostly in the relapsed tumors after chemotherapy (Fig. 1) [11]. MDM2 is a direct p53 antagonist leading to its tumor suppressor activity decrease.

A loss of miR-34a has been linked to chemoresistance of several cancers [7]. Several studies have reported that the three miR-34 microRNA family members that have been identified are direct targets of p53, and their ectopic expression can reproduce p53-mediated effects, including cell-cycle arrest and induction of apoptosis and senescence-like phenotypes, whereas inhibition of miR-34a functions impairs p53-induced apoptosis upon DNA damage induction. Similar to other p53-target genes, miR-34 genes may be the important targets for other signaling pathways involved in normal development [9]. miR-34a expression reduces glioma stemness and induces cell differentiation into astrocytes, neurons, and oligodendrocytes. Emerging evidence suggests a role for aberrant miRNA regulation in the NB. To date, several miR-34a targets have been experimentally validated, including CDK4/6, cyclin E2, cyclin D1, E2F5, MET, Bcl2, MYCN, and SIRT1. MiR-34a can simultaneously target the components of several signaling cascades involved in the NB tumorigenesis and, thus, the magnitude of miR-34a effects on protein expression changes that occur at early time points in the NB cells [2].

The aim of this study was to investigate the miR-34 microRNA family expression changes in the NB tumor samples and to determine their association with clinical features and disease outcome.

ISSN 1996-4536 (print) • ISSN 2311-0783 (on-line) • Біологічні Студії / Studia Biologica • 2016 • Том 10/№2 • C. 5-14 


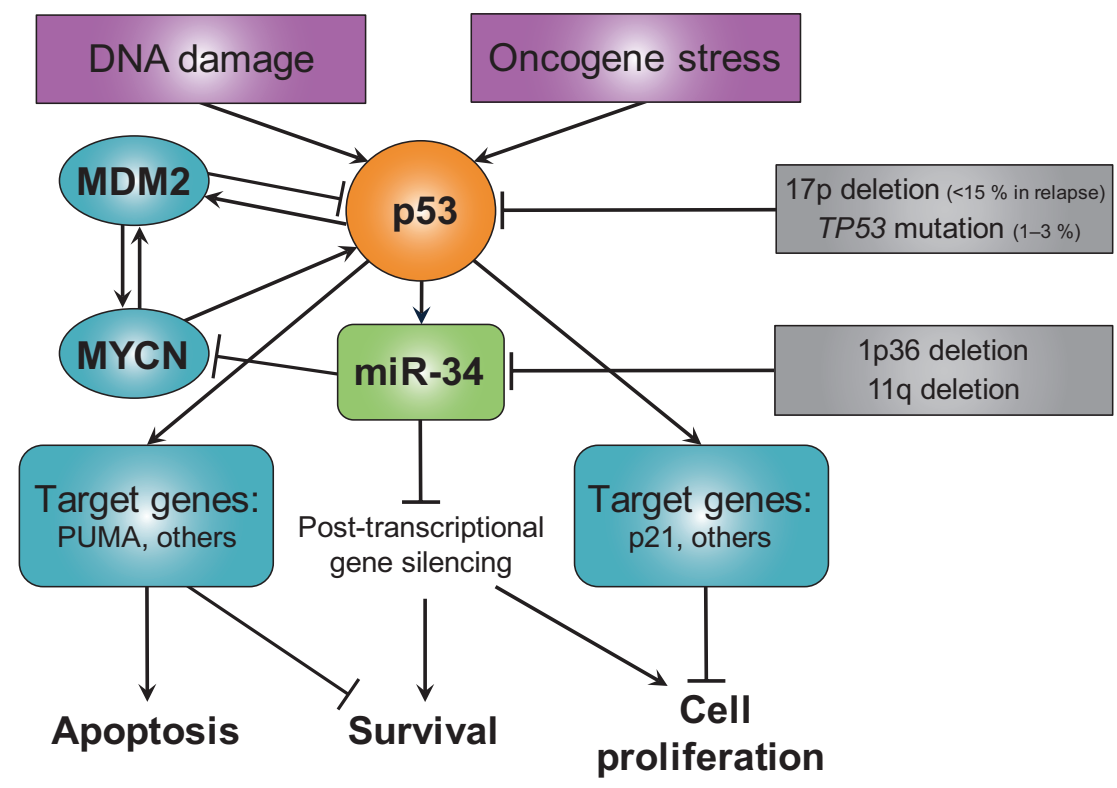

Fig. 1. Model of the p53/miR-34 network and its potential impairment in the NB ([6], modified and complemented).

DNA damage leads to activation of p53 that induces cell-cycle arrest through p21 and apoptosis through different targets including Puma. miR-34 is a direct transcriptional target of p53. miR-34 induces cell death through apoptosis and cell-cycle arrest through silencing of its potential targets. In the NB, different modes of interference in this model occur, including mutation/deletion of TP53 and down-regulation of miR-34 microRNA family members by their gene loci deletion or other way

Рис. 1. Модель взаємодії р53/мікроРНК-34 і її можливих порушень при нейробластомі ([6], змінено і доповнено).

Пошкодження ДНК активує р53, який спричиняє зупинку клітинного циклу через р21 і апоптоз за допомогою різних мішеней, включаючи Рuma. МікроРНК-34 є прямою транскрипційною мішенню р53. МікроРНК-34 індукує загибель клітин шляхом апоптозу і зупинки клітинного циклу через інгібування своїх потенційних мішеней. При нейробластомі виникають порушення цієї системи, включаючи мутації/делецію ТР53 і зниження активності членів родини мікроРНК-34 завдяки делеції локусів їх генів чи іншим способом

\section{MATERIALS AND METHODS}

Patients. Tumor samples were collected from 64 patients with verified NB before any cytoreductive treatment by biopsy or tumor resection. Written informed consent was obtained from patients' parents for tissue sampling according to the requirements of the protocol No. 35 from 1.03.2015 approved by Ethical Commission of the National Cancer Institute. All patients were considered sporadic cases on the basis that no family histories of the NB were reported. No patient received chemotherapy or radiotherapy before tumor sampling.

Samples processing and nucleic acids extraction. Fresh tumor samples for qPCR analysis were stored in RNA-later (Ambion, USA) for RNA and DNA stabilization. Total RNA and DNA were extracted from tissues using NucleoSpin MiRNA Kit (Macherey-Nagel, Germany) following the manufacturer's instructions. The final elution volume was $30 \mathrm{ml}$. The concentrations of all RNA samples were quantified by ThermoScientific NanoDrop-1000 (Thermo Fisher Scientific, USA). 
MicroRNA quantification by real-time quantitative RT-PCR. 30 ng of total RNA were reverse transcribed to cDNA with stem-loop primers and the TaqMan MicroRNA Reverse Transcription kit (Applied Biosystems, USA). Relevant TaqMan MicroRNA Assays (Applied Biosystems, USA) were used to quantify miR-34 (hsa-miR-34a, hsa-miR$34 \mathrm{~b}$ and hsa-miR-34c). Normalization was performed with the small nuclear RNA (snRNA) U6. This snRNA is stably expressed reference gene suitable for use as normalizer in TaqMan assays. Real-time qRT-PCR was performed with 7500 Real-Time PCR System (Applied Biosystems, USA). The cycle threshold (Ct) is defined as the number of cycles required for the fluorescent signal to cross the threshold in qPCR. Calculations were performed using the $\Delta \Delta$ Ct relative quantification method. Each sample was run in duplicates for analysis.

MYCN amplification and MDM2 expression analysis. TaqMan primers and probes were used to analyze genomic MYCN status in NB fresh tumors by real-time qPCR analysis and MDM2 expression level with real-time qRT-PCR. MYCN status and MDM2 expression were analyzed as previously described [5]. Results were normalized to relevant controls.

Statistical analysis. Gaussian distribution of the group was checked with Kolmogorov-Smirnov tests. Analysis of the association between the studied markers and clinical characteristics of patients was performed using U-Mann-Whitney test. Prognostic significance of markers was verified with the ROC-curve (Receiver Operating Characteristic curve). Overall survival was evaluated by Kaplan-Meier estimator, statistical significance of parameters differences was determined using F-Cox criterion. Overall survival time was calculated as the time from study enrollment until the time of death or the time of last contact if the patient was alive. The data were processed with the software package Statistica 6.1 using parametric and nonparametric methods of statistical analysis and MedCalc 12.1.4.0. The difference was considered statistically significant at $p<0.05$.

\section{RESULTS AND DISCUSSION}

Virtually all NBs have wild-type TP53 before treatment with chemotherapy, suggesting that the p53 pathway may be attenuated by another mechanism in these tumors [11]. We examined expression of miR-34a, b and $c$ in the NB tumors and found that a majority of them express detectable levels of miR-34a and extremely low levels of miR-34b and c (Fig. 2).

We compared the expression of microRNA-34a, b and c levels in human brain, normal adult neural tissue with the highest miR-34a expression. It was found that miR34a (Fig. 2, A) and c (Fig. 2, C) were detectable in all samples and mir-34b (Fig. 2, B) in $93 \%$ of primary NB, and all of them were substantially underexpressed comparing to normal brain level in most tumor NB samples. As expected, strong positive correlation between miR-34 microRNA family members (Spirman correlation analysis: miR-34a vs miR-34b: $R=0.8, p<0.05$; miR-34a vs miR-34c: $R=0.8, p<0.05 ;$ miR-34b vs miR-34c: $R=0.95, p<0.05)$ was found.

Analyzing miR-34 expression in both primary and secondary tumors, we concluded that miR-34 expression is reduced in metastasis and relapses (See Table). Direction of miR-34a,b and c expression were changed depending on NB clinical and biological characteristics, and they were similar for all microRNAs, although but statistically significant differences were observed only for miR-34a.

ISSN 1996-4536 (print) • ISSN 2311-0783 (on-line) • Біологічні Студії / Studia Biologica • 2016 • Том 10/№2 • С. 5-14 

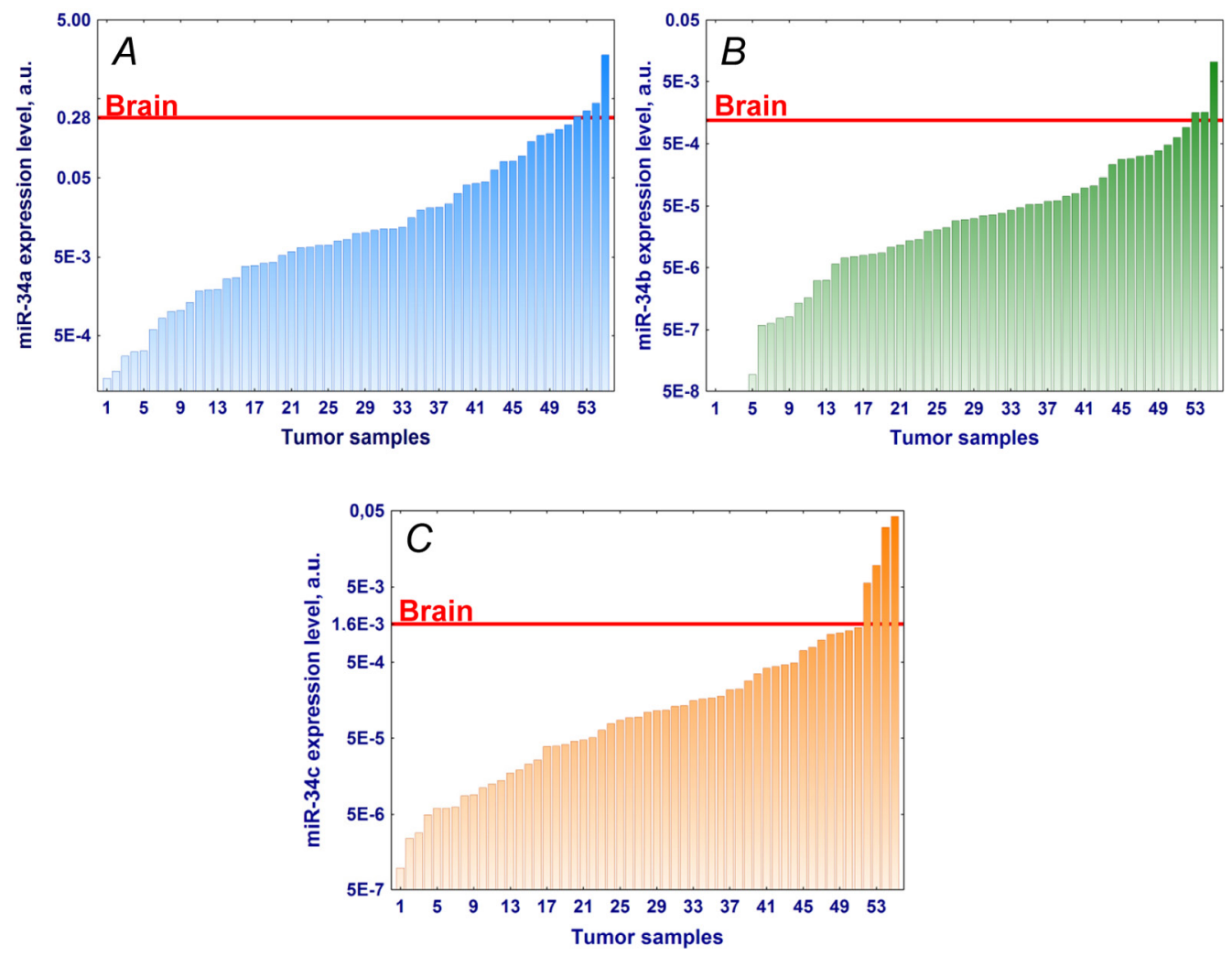

Fig. 2. Levels of expression of miR-34 microRNA family measured by qRT-PCR in primary human NB tumor samples

Comments: $A-$ miR-34a; $B-$ miR-34b and $C-$ miR-34c expression levels. Normal human brain expression is indicated by red thick line

Pис. 2. Рівні експресії родини мікроРНК miR-34, визначені за допомогою кількісної ЗТ-ПЛР у зразках первинних пухлин нейробластоми

Примітки: Рівні експресії мікроРHК: $A$ - miR-34a; $B$ - miR-34b i $C$ - miR-34c. Експресію в нормальній тканині головного мозку позначено червоною потовщеною лінією

Patients were divided by age on younger than 12 months, from 12 to 24 months, and patients 24 months age and older. Age of patient is an independent prognostic marker of the NB and it is used for patient stratification on risk groups. Patients under 2 years constitute a high risk group. In this study, we observed a significant decrease of miR-34 expression in older patients. Stage was dichotomized for the entire NB cohort with respect to metastatic progression. It was found that in patients with a diffused late-stage disease miR-34a expression level was lower than in patients with earlystages NB.

We also defined groups with different MYCN status and MDM2 expression levels that cause clinically aggressive NB course. The lowest level of miR-34a expression was observed in tumors with MYCN amplification and high MDM2 expression which are the markers of poor prognosis of the disease. 


\section{Clinical and biological characteristics and expression of miR-34 microRNA family in the NB tumors}

\section{Клінічні та біологічні характеристики й експресія родини мікроРHК miR-34} у пухлинах нейробластоми

\begin{tabular}{|c|c|c|c|c|c|}
\hline \multirow{2}{*}{\multicolumn{2}{|c|}{$\begin{array}{c}\text { Clinical and biological features } \\
\text { of NB }\end{array}$}} & \multirow[b]{2}{*}{ Number (\%) } & \multicolumn{3}{|c|}{ Median of miRNA expression level, a.u. } \\
\hline & & & miR-34a & miR-34b & miR-34c \\
\hline \multirow[b]{2}{*}{ Tumor type } & Primary & $55(86 \%)$ & 0.010 & 3.5 & 9.5 \\
\hline & $\begin{array}{l}\text { Metastatic and } \\
\text { recurrent }\end{array}$ & $9(14 \%)$ & $0.003^{*}$ & 1.4 & 4.1 \\
\hline \multicolumn{6}{|c|}{ PRIMARY TUMORS: } \\
\hline \multirow{3}{*}{$\begin{array}{l}\text { Age of } \\
\text { occurrence }\end{array}$} & under $12 \mathrm{~m}$ & $14(25 \%)$ & 0.008 & 1.6 & 1.4 \\
\hline & $12-24 \mathrm{~m}$ & $17(31 \%)$ & 0.006 & 3.5 & 9.4 \\
\hline & over $24 \mathrm{~m}$ & $24(44 \%)$ & $0.022^{+}$ & 5.8 & 10 \\
\hline \multirow{3}{*}{ Stage } & $I-I I$ & $10(18 \%)$ & 0.021 & 4.1 & 15 \\
\hline & III & $13(24 \%)$ & 0.007 & 2.3 & 9.3 \\
\hline & IV & $32(58 \%)$ & $0.009^{\#}$ & 3.1 & 9.1 \\
\hline \multirow{2}{*}{ MYCN status } & normal & $37(67 \%)$ & 0.018 & 4.7 & 12 \\
\hline & amplification & $18(33 \%)$ & $0.005^{\mathrm{a}}$ & $1.5^{\mathrm{a}}$ & 4.5 \\
\hline \multirow{2}{*}{$\begin{array}{l}\text { MDM2 } \\
\text { expression }\end{array}$} & high & 31 (56 \%) & 0.008 & 2.9 & 5.6 \\
\hline & low & $24(44 \%)$ & $0.032^{\S}$ & 5.5 & $17^{\S}$ \\
\hline
\end{tabular}

Comments: * $p<0.05$ comparing to primary tumors; ${ }^{+} p<0.05$ comparing to $12-24$ months group; ${ }^{*} p<0.05$ comparing to I-II stages; " $p<0.05$ comparing to MYCN gene single copy tumors; $\$ p<0.05 \mathrm{com}$ paring to MDM2 overexpressed tumors; a.u. - arbitrary units; $\mathrm{m}$ - months

Примітки: * $p<0,05$ порівняно з первинними пухлинами; ${ }^{+} p<0,05$ порівняно 3 групою 12-24 місяців; \# $p<0,05$ порівняно з I-ІІ стадіями; " $p<0,05$ порівняно з пухлинами з однією копією гена MYCN; ${ }^{\S}$ p $<0,05$ порівняно з пухлинами з підвищеним рівнем експресії MDM2; а.и. - умовні одиниці; m - місяці

In this study, we present evidence of miR-34a deregulation in the NB. A decrease of miR-34a expression is associated with unfavorable clinical and biological features of the disease. Alterations of miR34a expression may serve as additional marker for the optimization of patient stratification.

By using ROC-analysis, we could not obtain optimal criterion for the whole study cohort for distribution of patients according to miR-34a expression (Area under the ROC curve (AUC) - 0.65; $p=0.06$; Se - 32; Sp - 97), and did not confirm independent prognostic value of miR-34a expression in the NB. Next, we analyzed the most favorable and poor prognostic groups. In MYCN not-amplified NB with low MDM2 expression impact of MYCN and MDM2 in p53 regulation was excluded. We assessed with ROC-analysis the optimal criterions for distribution of patients on groups according to miR-34a expression 
for MDM2 overexpressed (optimal criterion: $\leq 0.0208$ a.u.; AUC - 0.72; Se- 78; Sp- 64; $\mathrm{p}<0.04$ ) and MYCN not-amplified NB with low MDM2 expression (optimal criterion: $\leq 0.0208$ a.u., AUC - 0.78; Se - 60; Sp - 88; p<0.05).
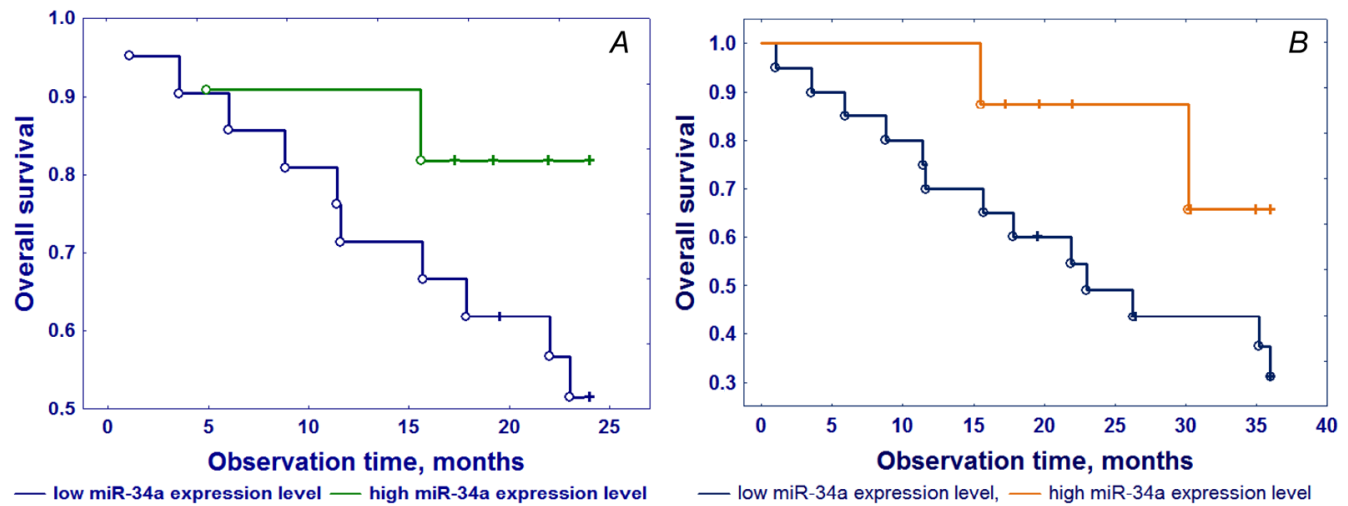

Fig. 3. Kaplan-Maier curves of the overall survival of patients with primary NB tumors according to miR-34a expression level

Comments: $A-M Y C N$ not-amplified NB with low MDM2 expression; $B$ - MDM2 overexpressed NB

Рис. 3. Криві загальної виживаності пацієнтів за Каплан-Майером відповідно до рівня експресії мікроРНК-34а у первинних пухлинах нейробластоми

Примітки: $A$ - нейробластома без ампліфікації MYCN і низьким рівнем експресії MDM2; $B$ - нейробластома з високим рівнем експресії MDM2

In MYCN not-amplified NB low MDM2 expressed NB 2-year overall survival was on $30 \%$ lower (Cox's F-test: $F=2.3 ; p=0.03$ ) in downregulated miR-34a cases compared to patients with high miR-34a expressed NB (83 and $53 \%$, respectively) (Fig. 3, A). Patients with MDM2 overexpression received treatment for high risk group from the beginning of the disease and often died from the chemotherapy toxicity. In this group, a decrease of miR-34a was associated with significant reduction of 3-year overall survival (61 vs $31 \%$, Cox's F-test: $F=2.4 ; p=0.04$ ) (Fig. 3, B). In both groups, low miR-34a expression was associated with a decrease of the survival rates.

\section{CONCLUSIONS}

In this study, we showed that a decrease of miR-34a expression is associated with unfavorable clinical and biological features of NB and a reduction of the overall survival. Analysis of mir-34a expression can serve as an additional marker for the optimization of patient stratification and help to improve personalized therapy strategy. Additional studies are needed to understand the mechanism for inactivation of miR-34a in the NB. Restoring of miR-34a expression may be a promising therapeutic strategy. 
1. Ambros P., Ambros I., Brodeur G. et al. International consensus for neuroblastoma molecular diagnostics: report from the International Neuroblastoma Risk Group (INRG) Biology Committee. Br. J. Cancer, 2009; 100(9): 1471-1482.

2. Antonellis De P., Carotenuto M., Vandenbussche J. et al. Early Targets of miR-34a in Neuroblastoma. Mol. Cell Proteomics, 2014; 13(8): 2114-2131.

3. Brodeur G. Neuroblastoma: biological insights into a clinical enigma. Nat. Rev. Cancer, 2003; 3(3): 203-216.

4. Hermeking $H$. The miR-34 family in cancer and apoptosis. Cell Death and Differ, 2010; 17(2): 193-199.

5. Inomistova M.V., Svergun N.M., Khranovska N.M. et al. Prognostic significance of MDM2 gene expression in childhood neuroblastoma. Exper. Oncol, 2015; 37(2): 111-115.

6. Lin H., Xingyue H., Scott $L$. et al. MicroRNAs join the p53 network - another piece in the tumour-suppression puzzle. Nat. Rev. Cancer, 2007; 7(11): 819-822.

7. Lodygin D., Tarasov V., Epanchintsev A. et al. Inactivation of miR-34a by aberrant CpG methylation in multiple types of cancer. Cell Cycle, 2008; 7(16): 2591-2600.

8. Look A., Hayes F., Shuster J. et al. Clinical relevance of tumor cell ploidy and N-myc gene amplification in childhood neuroblastoma: a Pediatric Oncology Group study. J. Clin. Oncol, 1991; 9(4): 581-591.

9. Raver-Shapira N., Marciano E., Meiri E. et al. Transcriptional activation of miR-34a contributes to p53-mediated apoptosis. Mol Cell, 2007; 26(5): 731-743.

10. Schwab M., Westermann F., Hero B. et al. Neuroblastoma: biology and molecular and chromosomal pathology. Lancet Oncol, 2003; 4(8): 472-480.

11. Tweddle D., Malcolm A., Bown N. et al. Evidence for the development of p53 mutations after cytotoxic therapy in a neuroblastoma cell line. Cancer Res, 2001; 61(1): 8-13.

\title{
ЕКСПРЕСІЯ мікРОРНК РОДИНИ miR-34 ТА КЛІНІЧНИЙ ПЕРЕБІГ НЕЙРОБЛАСТОМИ
}

\author{
М. Іномістова ${ }^{1,2}$, Н. Храновська \\ O. Скачкова ${ }^{1}$, Е. Шайда' ${ }^{1}$, C. Демидов ${ }^{2}$ \\ ${ }^{1}$ Національний інститут раку \\ вул. Ломоносова, 33/43, Київ 03022, Україна \\ e-mail:m.inomistova@gmail.com \\ 2 Київський національний університет імені Тараса Шевченка \\ вул. Володимирська, 64, Київ 01601, Україна
}

Нейробластома є одним із найпоширеніших дитячих онкологічних захворювань, що виникає з тканин симпатичної нервової системи з високим рівнем захворюваності в Україні. Генетичні аномалії, такі як втрати хромосомних ділянок 1 p36 і 11q і ампліфрікація гена $M Y C N$, тісно пов'язані з несприятливим прогнозом захворювання.

Незважаючи на рідкість мутацій гена TP53, p53 шлях є часто інактивованим при нейробластомі здебільшого через надлишкову експресію MDM2. МікроРНК родини мікроРНК-34 є найбільш відомими р53-індукованими мікроРНК і важливими медіаторами онкосупресії. Родина мікроРНК-34 складається з трьох членів: мікроРНК-34а кодується своїм власним транскриптом з 1р36, тоді як мікроРНК-34b і мікроРНК-34с ділять загальний первинний транскрипт на 11q. Припускається, що 
мікроРНК-34а є супресором пухлинного розвитку при нейробластомі, оскільки його мішенями є безліч онкогенів, таких як E2F3, BCL-2 і MYCN.

У цьому дослідженні ми наводимо докази порушення експресії мікроРНК-34 при нейробластомі. Зниження експресії мікроРНК-34 пов'язано з несприятливими клінічними і біологічними особливостями захворювання. Низький рівень експресії мікроРНК-34а був асоційований зі зниженням показників виживаності у пацієнтів групи з надескпресією MDM2 і групи без ампліфікації гена $M Y C N$ і низьким рівнем експресії MDM2. Беручи це до уваги, визначення експресії мікроРНК-34а може бути корисним для вдосконалення стратегії персоналізованої терапії та може слугувати додатковим маркером для оптимізації стратифікації пацієнтів з нейробластомою.

Ключові слова: нейробластома, родина мікроРНК-34, експресія, клінічний перебіг захворювання.

\title{
ЭКСПРЕССИЯ МИКРОРНК СЕМЕЙСТВА miR-34 И КЛИНИЧЕСКОЕ ТЕЧЕНИЕ НЕЙРОБЛАСТОМЫ
}

\author{
М. Иномистова ${ }^{1,2}$, Н. Храновская ${ }^{1}$ \\ О. Скачкова ${ }^{1}$, Э. Шайда' ${ }^{1}$, С. Демидов \\ ${ }^{1}$ Национальный институт рака \\ ул. Ломоносова, 33/43, Киев 03022, Украина \\ e-mail:m.inomistova@gmail.com \\ ${ }^{2}$ Киевский национальный университет имени Тараса Шевченко \\ ул. Владимирская, 64, Киев 01601, Украина
}

Нейробластома является одним из самых распространенных детских онкологических заболеваний, которое возникает из тканей симпатической нервной системы с высоким уровнем заболеваемости в Украине. Генетические аномалии, такие как потеря хромосомных участков 1р36 и 11q, амплификация гена MYCN тесно связаны с неблагоприятным прогнозом заболевания.

Несмотря на редкость мутаций гена TP53, р53 путь часто является инактивированным при нейробластоме, в основном из-за избыточной экспрессии MDM2. МикроРНК семьи микроРНК-34 являются наиболее известными р53-индуцированными микроРНК и важными медиаторами онкосупрессии. Семья микроРНК-34 состоит из трех членов: микроРНК-34а кодируется своим собственным транскриптом с 1р36, в то время как микроРНК-34b и микроРНК-34c делят общий первичный транскрипт на 11q. Предполагается, что микроРНК-34а является супрессором опухолевого развития при нейробластоме, поскольку его мишенями являются множество онкогенов, таких как E2F3, BCL-2 и MYCN.

В этом исследовании мы приводим доказательства нарушения экспрессии микроРНК-34 при нейробластоме. Снижение экспрессии микроРНК-34 связано с неблагоприятными клиническими и биологическими особенностями заболевания. Низкий уровень экспрессии микроРНК-34а был ассоциирован со снижением показателей выживаемости у пациентов группы со сверхэкспрессией MDM2

ISSN 1996-4536 (print) • ISSN 2311-0783 (on-line) • Біологічні Студії / Studia Biologica • 2016 • Том 10/№2 • С. 5-14 
и группы без амплификации гена MYCN и низким уровнем экспрессии MDM2. Принимая это во внимание, определение экспрессии микроРНК-34а может быть полезным для усовершенствования стратегии персонализированной терапии и может служить дополнительным маркером для оптимизации стратификации пациентов с нейробластомой.

Ключевые слова: нейробластома, семейство микроРНК-34, экспрессия, клиническое течение заболевания.

Одержано: 01.07.2016 